\title{
Salivary leptin induces increased expression of growth factors in oral keratinocytes
}

\author{
M Gröschl, H-G Topf*, J Kratzsch'1, J Dötsch, W Rascher and M Rauh \\ Department of Paediatrics, University of Erlangen-Nürnberg, Germany \\ ${ }^{1}$ Institute for Laboratory Medicine, University of Leipzig, Germany \\ (Requests for offprints should be addressed to M Gröschl, Klinik für Kinder und Jugendliche, Loschgestrasse 15, 91054 Erlangen, Germany; \\ Email: michael.groeschl@ kinder.imed.uni-erlangen.de) \\ *(M Gröschl and H-G Topf contributed equally to this work)
}

\begin{abstract}
We investigated the influence of salivary leptin, purified by affinity chromatography, on the proliferation of human oral keratinocytes. Furthermore we determined the time- and dose-dependency of the incubation with salivary leptin on the production of epidermal growth factor (EGF) and keratinocyte growth factor (KGF), which are growth factors relevant to keratinocyte proliferation. The analysis was performed both intra- and extracellularly. The relationship between the three cytokines in cell proliferation was studied by successive blocking with specific antibodies. The incubation of oral keratinocytes with recombinant and native leptin led to a significantly increased, dose-dependent cell proliferation $(P<0.001)$. A further significant increase in proliferation was observed after incubating the cells with sterile filtered saliva $(P<0.001)$. The increase in proliferation could not be observed by simultaneous incubation with salivary leptin and specific antibodies against either leptin or KGF $(P<0.001)$. We found a significant dose-dependency between leptin incubation and production of KGF and EGF at the RNA and protein level. Both cytokines were expressed intracellularly and released into the culture medium, where they could be quantified by ELISA. Furthermore, there was a dose- and time-dependent increase in the phosphorylation of STAT-1 and STAT-3, indicating that Ob- $\mathrm{R}_{\mathrm{b}}$ (the long form of the leptin receptor) expressed by the keratinocytes is functional. It is conceivable that the leptin-induced proliferation in keratinocytes is mediated by this signalling pathway. This is the first study to show a physiological role of salivary leptin as a growth factor for keratinocyte proliferation in the oral cavity. We could demonstrate its influence on the production of other growth factors essential for this proliferative effect. Based on the findings of our study we assume an important role for salivary leptin in wound healing within the vulnerable oral cavity.
\end{abstract}

Journal of Molecular Endocrinology (2005) 34, 353-366

\section{Introduction}

Leptin was first described as an adipocyte-derived hormone (Zhang et al. 2000) influencing food intake and energy expenditure by interaction with receptors in the feeding centres of the hypothalamus (Elmquist et al. 1997). However, increasing numbers of publications demonstrate that this cytokine is also produced by other tissues, such as the placenta (Zhao et al. 2003), gastric mucosa (Sobhani et al. 2002) and neuronal tissues (Morash et al. 1999). In addition to the well-described influence of leptin on nutrition, multiple peripheral metabolic effects of this hormone have been discussed (Muoio \& Dohm 2002).

Previous investigations of leptin in human saliva (Gröschl et al. 2001, 2002, Randeva et al. 2003) and its influence on the growth and weight of the salivary glands in rodents (Higa et al. 2002) indicate that, in addition to the circulating cytokine, local leptin production might play an important role in digestion or wound healing in the gastrointestinal tract. The idea of an autonomous glandular leptin production and active release into saliva is supported by the localisation of leptin within salivary microglobules, whereas seromucous material was negative (De Matteis et al. 2002).

The hypothesis of the current study was that leptin found in human saliva is biologically active and affects the proliferation of oral mucosal cells in vitro. This hypothesis is supported by previous publications describing the beneficial influence of leptin on wound healing in the gastrointestinal tract (Brzozowski et al. 1999, Konturek et al. 2001) and proliferation of various other tissues and cell lines (Wolf et al. 1999, Martin Romero et al. 2000, Hu et al. 2002, Wu et al. 2002). Previous studies demonstrating the beneficial effect of leptin on the proliferation of cutaneous keratinocytes in rodents were of special interest for our current investigation (Frank et al. 2000). Interestingly, in murine leukaemic cells this pro-proliferative effect can be inhibited by blocking the receptor with specific antibodies (Iversen et al. 2002).

Leptin receptors (Ob-Rs) are located ubiquitously (Halaas \& Friedman 1997) and are present in various 
receptor isoforms (Sweeney 2002) inducing different modes of signal transduction. Research has focused on the long receptor isoform $\mathrm{Ob}-\mathrm{R}_{\mathrm{b}}$, which causes phosphorylation of a receptor-bound janus kinase (JAK) using STAT proteins as second messengers (Rosenblum et al. 1996, Wang et al. 1996, Hakansson \& Meister 1998, Banks et al. 2000). In the cutaneous keratinocytes of humans and rodents, JAK/STAT signalling has been described as the main second messenger pathway induced by leptin (Stallmeyer et al. 2001, Goren et al. 2003). Other truncated isoforms, in particular the soluble receptor, seem to have a leptin-binding function rather than a signal-transducing function (Lammert et al. 2001). Recently, functional Ob-R were identified in the gastric mucosa (Breidert et al. 1999) and in other parts of the gastrointestinal tract (Morton et al. 1998). The role of salivary leptin in the biology of the oral and gastrointestinal mucosa remains to be fully elucidated.

It was the objective of the present study to answer this question by investigating the effect of salivary leptin on the proliferation of primary keratinocytes derived from the oral cavity of healthy humans. Moreover, we sought to demonstrate the interaction between salivary leptin with other cytokines. Our interest focused on the analysis of the epidermal growth factor (EGF) and the keratinocyte growth factor (KGF; FGF-7), both well known for being involved in the proliferation of keratinocytes and wound healing (Alison \& Sarraf 1994, Slonina et al. 2001).

\section{Materials and methods}

\section{Cell culture}

Primary human oral non-gingival keratinocytes obtained from healthy subjects (Lauer et al. 2001) were cultured in a $5 \% \quad \mathrm{CO}_{2}$ humidified atmosphere at $37^{\circ} \mathrm{C}$ in Keratinocyte-SFM medium (Invitrogen) supplemented with bovine pituitary gland extract and EGF, containing $100 \mathrm{U} / \mathrm{ml}$ penicillin, and $100 \mathrm{mg} / \mathrm{ml}$ streptomycin (Sigma). During the experiments the culture medium was not supplemented with EGF or KGF.

\section{Isolation and purification of salivary leptin}

Saliva from healthy volunteers was collected $(\sim 500 \mathrm{ml})$ using a Salivette with polyester swabs (Sarstedt, Nürnbrecht, Germany). Saliva was pooled, filtered and centrifuged to remove cellular and mucous components $(4000 \boldsymbol{g} ; 1 \mathrm{~h})$. For the purification of salivary leptin, we extracted the clear solution using N-hydroxysuccinimide (NHS)-activated columns (HiTrap, $1 \mathrm{ml}$; Amersham Pharmacia) coated with leptin-specific antibodies. Ligand coupling was performed using a standard coupling buffer $\left(0 \cdot 2 \mathrm{M} \mathrm{NaHCO}_{3}, 0 \cdot 5 \mathrm{M} \mathrm{NaCl}\right.$; $\mathrm{pH}$ 8.3). After equilibration of the column with ten volumes of
PBS buffer, $\mathrm{pH} 7 \cdot 4$, saliva was applied in $1 \mathrm{ml}$ portions to the column (flow rate $0 \cdot 2-1 \mathrm{ml} / \mathrm{min}$ ). During this step of the procedure leptin binds to the antibodies. After repeated washing steps (five column volumes PBS; pH $7 \cdot 4$ ) salivary leptin was eluted by alteration of the $\mathrm{pH}$ value (three column volumes $100 \mathrm{mM}$ glycine $/ 0.5 \mathrm{M}$ $\mathrm{HCl}$; pH 2.7). The elute was buffered with Tris buffer $(\mathrm{pH} 9)$. The leptin content of the elution buffer was determined by RIA (Gröschl et al. 2000). The material was lyophilised and stored at $-80{ }^{\circ} \mathrm{C}$ until use.

\section{Expression of cytokines}

The influence of salivary leptin on the expression of EGF and KGF was examined by culturing the cells in six-well plates (Falcon, Heidelberg, Germany). Cells were sown in plates at a density of $2 \times 10^{6} /$ well. After $48 \mathrm{~h}$ the medium was changed to contain either $0,1 \cdot 2$, $2 \cdot 5,5,10$ or $20 \mathrm{ng} / \mathrm{ml}$ salivary leptin in the six different wells of the plates. After 24, 48 and $72 \mathrm{~h}$ two of each of the plates were harvested. The medium was collected for the analysis of extracellular proteins, the cells were harvested for Western blot analysis in SDS/ mercaptoethanol lysis buffer and Trizol reagent for PCR determination.

\section{Cell proliferation experiments}

The direct determination of cell proliferation by counting cells was inconvenient, due to the nonhomogeneous shape of our adherent epithelial cells. Therefore we decided to use an indirect method by determination of the DNA synthesis during mitosis.

In the first experiment, keratinocytes were transferred to sterile 96-well microtitre plates (MTPs) (Falcon) at a density of $2 \times 10^{3}$ cells/well. After adhesion of the cells $(24 \mathrm{~h})$, the culture medium was changed, containing either $0,1 \cdot 2,2 \cdot 5,5,10$ or $20 \mathrm{ng} / \mathrm{ml}$ recombinant human leptin (Sigma). The different leptin concentrations were placed in ascending order within the MTPs.

The second experiment was carried out using salivary leptin purified as described above and adjusted to the same concentrations as in the first experiment.

In the third experiment, geometrically diluted $(1 / 1$ to $1 / 8$; in sterile PBS) and sterile-filtered (Minisart $0 \cdot 45 \mu \mathrm{m}$; Sartorius, Göttingen, Germany) saliva was added to the culture medium.

A fourth experiment was designed in order to determine the relationship between salivary leptin and EGF and KGF in keratinocyte proliferation. Cells in these MTPs were incubated with salivary leptin $(10 \mathrm{ng} / \mathrm{ml})$. Additionally, antibodies against either leptin, EGF or KGF were added in ascending order to the rows of the MTPs. As controls, we added rows including either no antibodies or rabbit IgG (RIA grade; 
Sigma) to exclude any apoptotic effects of the rabbit immunglobulins on human cells.

In a final experiment we sought to investigate how far salivary leptin is responsible for oral mucosal proliferation in native saliva. For this reason we prepared saliva free of leptin, EGF or KGF by immunprecipitation of the cytokines with specific rabbit antibodies and goat anti-rabbit secondary antibodies. Keratinocytes were stimulated with saliva (1:1 in medium), and each of the cytokine-free aliquots. PBS replaced saliva in the controls.

After $24 \mathrm{~h}$ incubation, 5-bromo-2'-deoxyuridine (BrdU), a pyrimidine analogue, was added to the wells. The incorporation of BrdU during mitosis is an accepted measure of cell proliferation via assessment of DNA synthesis (Tsuchiya et al. 1999, Yoshizawa et al. 2000). The cell proliferation assay was purchased from Roche (Mannheim, Germany). After BrdU incorporation and fixation of the cells, a BrdU-specific antibody was added and, after further incubation, the turnover of the substrate tetramethylbenzidine was measured at $370 \mathrm{~nm}$. In order to avoid edging effects, only the ten inner samples of each row of the MTPs were used.

\section{Molecular biology}

\section{RNA extraction and reverse transcription}

Total RNA was extracted from the cells using guanidine-thiocyanate acid phenol (Trizol; WAK Chemie, Medical GmbH, Bad Homburg, Germany). RNA concentrations were determined spectrophotometrically. One microgram of RNA was reverse transcribed in a volume of $20 \mu \mathrm{l}$ at $39^{\circ} \mathrm{C}$ for $60 \mathrm{~min}$ (chemicals from Boehringer Mannheim, Germany).

\section{TaqMan real-time $P C R$}

The method has been validated in our laboratory and successfully used before. This method is based upon the $5^{\prime}$ exonuclease activity of the Taq polymerase. Briefly, within the amplicon defined by a gene-specific oligonucleotide primer pair a oligonucleotide probe labelled with two fluorescent dyes is designed. As long as the probe is intact, the emission of a reporter dye (i.e. 6-carboxy-fluorescein, FAM) at the $5^{\prime}$-end is quenched by the second fluorescence dye (6-carboxy-tetramethylrhodamine, TAMRA) at the 3 '-end. During the extension phase of the PCR, the Taq polymerase cleaves the probe releasing the reporter dye. An automated photometric detector combined with a special software (ABI Prism 7700 Sequence Detection System; Perkin-Elmer Applied Biosystems, Foster City, CA, USA) monitors the increasing reporter dye emission. The algorithm normalises the signal to an internal reference $(\Delta \mathrm{Rn})$ and calculates the threshold cycle number $\left(\mathrm{C}_{\mathrm{T}}\right)$, when the $\Delta \mathrm{Rn}$ reaches 10 times the standard deviation of the baseline. The $\mathrm{G}_{\mathrm{T}}$ values of the probes are interpolated to an external reference curve constructed by plotting the relative or absolute amounts of a serial dilution of a known template vs the corresponding $\mathrm{C}_{\mathrm{T}}$ values.

Commercial reagents (TaqMan PCR Reagent Kit; Perkin-Elmer) and conditions according to the manufacturer's protocol were employed. cDNA $(2 \cdot 5 \mu \mathrm{l})$ (reverse transcription mixture) and oligonucleotides with a final concentration of $300 \mathrm{nM}$ of primers and $200 \mathrm{nM}$ of TaqMan hybridisation probe were added to $25 \mu \mathrm{l}$ reaction mix. The oligonucleotides of each target of interest were designed using the Primer Express software (Perkin-Elmer) using uniform selection parameters that allowed the application of the same cycle conditions confirmed by primer optimisation. All of the primers and probes were purchased from Perkin-Elmer and Eurogentec (Liège, Belgium). The thermocycler parameters were $50{ }^{\circ} \mathrm{C}$ for $2 \mathrm{~min}, 95^{\circ} \mathrm{C}$ for $10 \mathrm{~min}$ followed by 40 cycles of $94^{\circ} \mathrm{C}$ for $15 \mathrm{~s}$ and $60^{\circ} \mathrm{C}$ for $1 \mathrm{~min}$. Serial dilutions of one of the samples served as a reference providing relative quantification of the unknown samples.

EGF and KGF gene expression was related to the housekeeping genes glyceraldehyde-3-phosphate dehydrogenase (GAPDH) and $\beta$-actin. For primers and TaqMan probes see Table 1 .

\section{Protein analysis}

\section{ELISA}

Specific immunoassays for the analysis of EGF and KGF in the culture medium were purchased from $\mathrm{R} \& \mathrm{D}$ Systems (Wiesbaden, Germany; \#DEG00 and DKG00). Sample volumes required per assay were $200 \mu \mathrm{l}$ for EGF and $100 \mu \mathrm{l}$ for KGF. Neither assay had obvious cross-reactivates to other cytokines. The linear range for measurement was 3.9-250 pg/ml for EGF and 31.2$2000 \mathrm{pg} / \mathrm{ml}$ for KGF. Limits of detection were listed at $0.7 \mathrm{pg} / \mathrm{ml}$ (EGF) and $15 \mathrm{pg} / \mathrm{ml}$ (KGF). Detailed information on the assays are provided in the product information.

\section{Immunoblots}

The proteins of the keratinocyte lysates were separated on 10-20\% gradient SDS-polyacrylamide gels and transferred to PVDF membranes (Roth, Karlsruhe, Germany). Analysis was performed using polyclonal rabbit antisera raised against the soluble Ob-R. Detailed specification is provided in the original publication (Lammert et al. 2001). Monoclonal antibodies raised against human EGF and KGF were purchased from R\&D Systems (\#MAB236 and \#AF-251-NA), poly- 


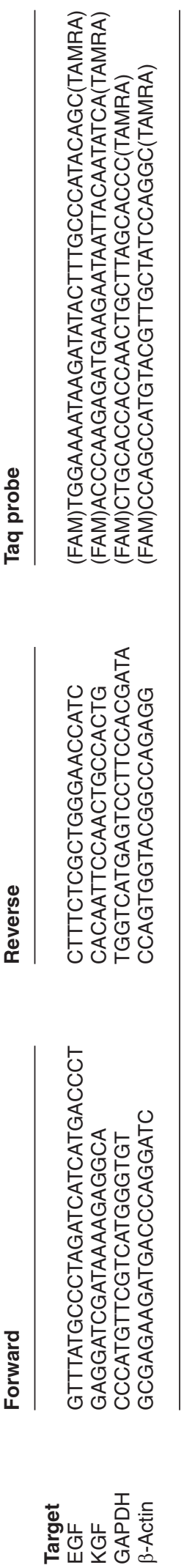

clonal antibodies raised against the specific cytokine receptors EGF-R and KGF-R were purchased from New England Biolabs (Frankfurt, Germany; \#2232) and Acris Antibodies (Hiddenhausen, Germany; \#AB5476). Detailed information on these antibodies are provided in the product information. All antibodies were used in a dilution of 1:1000 in blocking buffer (Roth). Protein markers were obtained either from New England Biolabs (biotin-labelled protein ladder) or from BioRad (colour-labelled protein markers).

\section{Analysis of leptin signalling}

The course in phosphorylation of STAT proteins over time was investigated in keratinocytes after incubation with $20 \mathrm{ng} / \mathrm{ml}$ recombinant leptin for 5, 10, 15 and $40 \mathrm{~min}$. In an additional experiment keratinocytes were incubated with logarithmically increasing leptin concentrations between 0.01 and $100 \mathrm{ng} / \mathrm{ml}$ for $15 \mathrm{~min}$. Untreated keratinocytes served as controls. Additionally, interferon (IFN)- $\alpha$-treated HeLa cells served as positive and untreated HeLa cells served as negative controls (New England Biolabs).

After washing with PBS, $0.5 \mathrm{ml}$ of lysis buffer (SDS/mercaptoethanol) was added to the cells. After 5 min of lysis, the cell suspension was heated to $90{ }^{\circ} \mathrm{C}$ for $10 \mathrm{~min}$. After cooling on ice, samples were centrifuged and transferred to $12 \%$ SDS gels. The sample material was adjusted to a standardised protein content.

Proteins were blotted to nitrocellulose membranes (Roth). After blocking the membranes with 5\% fat-free milk in PBS, the membranes were incubated overnight $\left(4{ }^{\circ} \mathrm{C}\right)$ with monoclonal antibodies against phosphorylated and non-phosphorylated STAT-3 and STAT-1 (New England Biolabs; \#9176; \# 9132).

The immune complexes were visualised on $\mathrm{X}$-ray films (Kodak, Stuttgart, Germany) using alkaline phosphatase-conjugated goat anti-rabbit secondary antibodies (BioRad, Munich, Germany) for the cytokine and cytokine receptor blots, or horseradish peroxidaselabelled goat anti-rabbit antibodies (New England Biolabs) for STAT protein blots. For localisation of the banding, colour-labelled (BioRad) or biotinylated marker proteins (New England Biolabs) were used.

\section{Data calculation and statistics}

ANOVA (Kruskal-Wallis with Dunn's multiple comparison test) was used to calculate significance of differences in cytokine production and BrdU incorporation. A $P$ value below 0.05 was considered significant. Values of cytokine release into the culture medium are provided as concentrations. Furthermore the values where normalised to the cytokine content of the daily non-stimulated control sample, set as baseline level. 

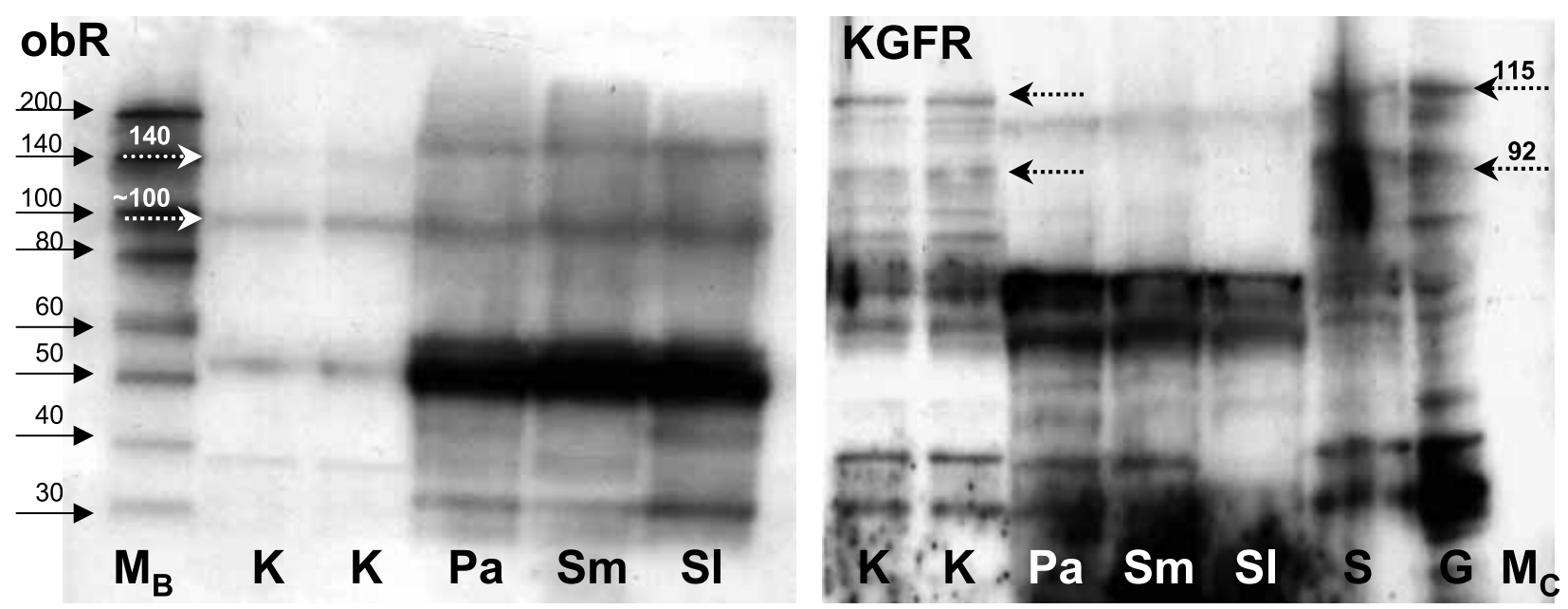

Figure $1 \mathrm{Immunoblotting} \mathrm{of} \mathrm{Ob-R} \mathrm{and} \mathrm{KGF-R} \mathrm{from} \mathrm{primary} \mathrm{buccal} \mathrm{keratinocytes} \mathrm{and} \mathrm{salivary} \mathrm{gland} \mathrm{lysates} \mathrm{(20} \mu \mathrm{g} / \mathrm{lane})$. The receptors were localised at molecular masses of approximately 90 and $140(\mathrm{Ob}-\mathrm{R})$ and 92 and 115 (KGF-R) kDa. Protein analysis was performed from two different keratinocyte cell lines $(\mathrm{K})$, parotid $(\mathrm{P})$ submandibular $(\mathrm{Sm})$ and sublingual (SI) gland. For KGF, gastric $(S)$ and gut $(G)$ mucosal cells were taken as positive controls. $M_{B}$ : biotinylated marker. $M_{C}$ : colour-labelled protein marker (not visible on $\mathrm{X}$-ray film).

\section{Results}

\section{Expression of cytokine receptors}

Using Western blot analysis of non-stimulated human oral keratinocytes, we found that the receptors for leptin, KGF and EGF were being expressed by the cells. The receptors displayed molecular masses of approximately 100 and 140 (Ob-R; Fig. 1a), 92 and 115 (KGF-R; Fig. 1b) and 175 (EGF-R, data not shown) kDa. The molecular masses are in accord with the data provided by the manufacturers of the antibodies and the literature (Marchese et al. 1995, Hackel et al. 1999, Shintani et al. 1999, Zwick et al. 1999, Lammert et al. 2001, Visco et al. 2004) and indicate that oral keratinocytes are potential targets for the three cytokines which are the focus of our investigations. The heavier Ob-R fragment with the expected size of $140 \mathrm{kDa}$ was very weak in the keratinocytes, whereas the lighter band was well expressed in the cells and glandular tissues. The KGF-R was also weak but present in the keratinocytes and in line with the bands of the positive controls from gastric and gut mucosa. Interestingly, the salivary glands did not significantly express either band of the KGF-R.

\section{Signal transduction}

It was our aim to prove the functionality of the $\mathrm{Ob}-\mathrm{R}_{\mathrm{b}}$ receptor isoform being expressed by oral keratinocytes. Potential transducers of this proliferative effect after incubation with leptin are STAT proteins. After incubation of oral keratinocytes with $20 \mathrm{ng} / \mathrm{ml}$ human leptin, phosphorylation of STAT-1 and STAT-3 was obviously upregulated in a time- and dose-dependent manner. In our experiments the most intense bands for STAT-1P (STAT-1 $\alpha 91 \mathrm{kDa}$; STAT-1 $\beta \quad 84 \mathrm{kDa})$ and STAT-3P (STAT-3 $\alpha 79 \mathrm{kDa}$; STAT-3 $\beta$ $86 \mathrm{kDa}$ ) were observed after 30 and $15 \mathrm{~min}$ of incubation respectively (Fig. 2a and b). Interestingly, even very small concentrations of leptin $(0 \cdot 1 \mathrm{ng} / \mathrm{ml})$ led to a detectable phosphorylation of STAT-1 (Fig. 2a). The much higher intensity of the non-phosphorylated signal peptides is presented as a loading control in both figures. This finding proves the functionality of the $\mathrm{Ob}-\mathrm{R}_{\mathrm{b}}$ isoform expressed in the oral mucosa (Bohlender et al. 2003). It remains to be determined whether this way of signal transduction is responsible for the increased cell proliferation.

\section{Expression of cytokines}

The levels of specific mRNA for both EGF and KGF increased dose-dependently on day 1 and day 2 after the leptin stimulus $(P<0.001)$ with lower expression of EGF. On day 3, however, the specific mRNA expression dropped down to a level as low as the initial value of non-stimulated cells. Since data of day 1 and 2 looked very similar, we decided to present the mean of the 2 days for both cytokines in Fig. 3. All values were normalised to the housekeeping genes $\beta$-actin and GAPDH.

We found EGF and KGF expressed intracellularly in leptin-stimulated cells. In addition to the specific banding for EGF (6 kDa; Fig. 4a) and KGF ( $20 \mathrm{kDa}$; expected size $21 \mathrm{kDa}$; Fig. 4b), additional bands were found for both cytokines. However, we could not find significant differences in the intensity of the bands in 
(a)

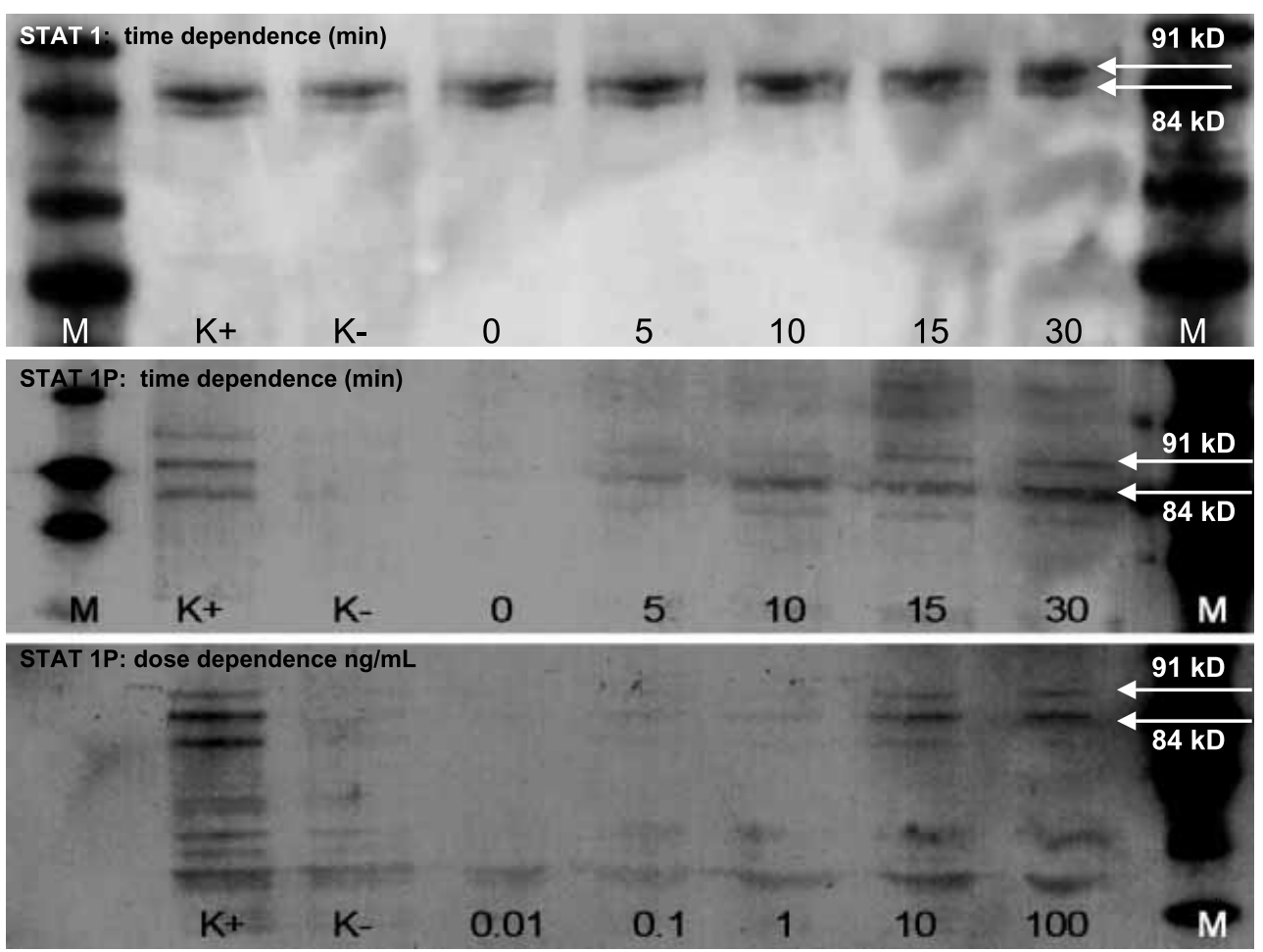

(b)

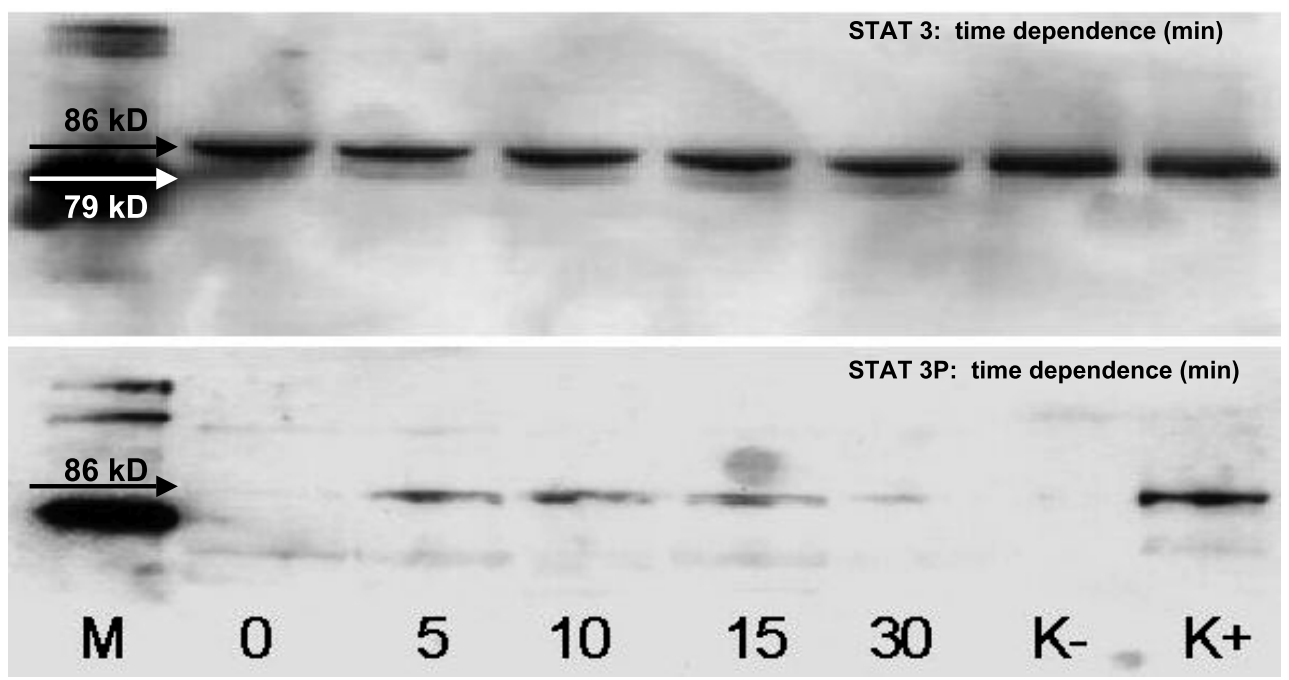

Figure 2 (a) Time- and dose-dependency of STAT-1 and STAT-1P in human oral keratinocytes after incubation with $20 \mathrm{ng} / \mathrm{ml}$ leptin for $0,5,10,15$ and $30 \mathrm{~min}$, or with logarithmically ascending doses $(0.01,0.1,1,10,100 \mathrm{ng} / \mathrm{ml})$ of leptin for $15 \mathrm{~min}$. IFN- $\alpha$-treated HeLa cells served as positive $(\mathrm{K}+)$, untreated keratinocytes ( $0 \mathrm{~min})$ and HeLa cells $(\mathrm{K}-)$ as negative controls. M: biotinylated protein marker. STAT-1 $\alpha$ : $91 \mathrm{kDa}$; STAT-1 $\beta: 84 \mathrm{kDa}$. (b) Western Blot analysis of STAT-3 and STAT-3P after incubation of human oral keratinocytes with $20 \mathrm{ng} / \mathrm{ml}$ leptin for up to $30 \mathrm{~min}(0,5,10,15$ and $30 \mathrm{~min}$; $20 \mathrm{\mu g}$ protein/lane). IFN- $\alpha$-treated HeLa cells served as positive $(\mathrm{K}+)$, untreated keratinocytes $(0 \mathrm{~min})$

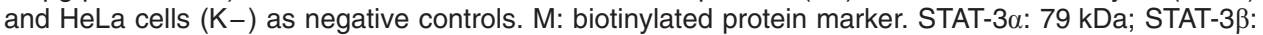
$86 \mathrm{kDa}$. 


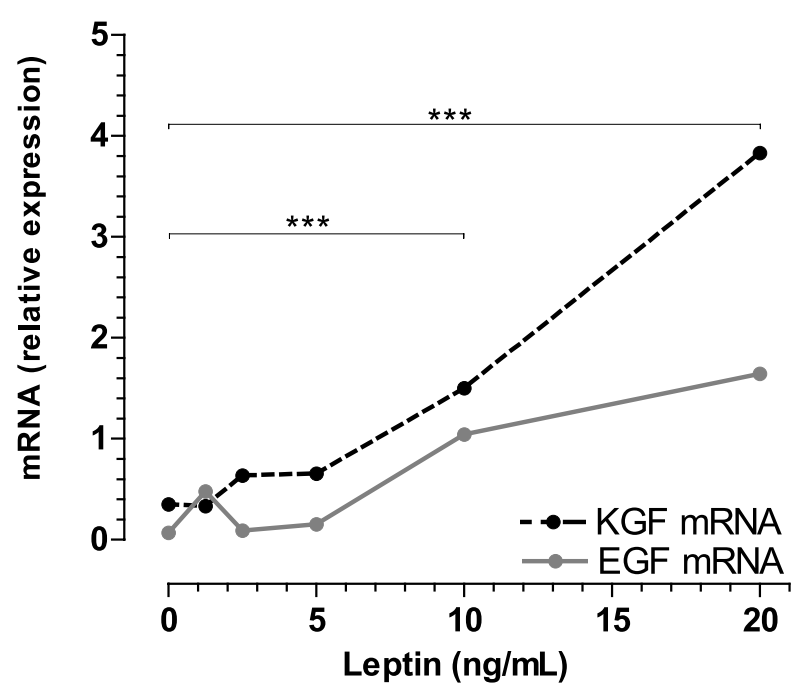

Figure 3 Dose-dependent expression of mRNA specific for EGF and KGF in human buccal keratinocytes following incubation with salivary leptin. Due to a very similar expression, data are shown as means of day 1 and 2 after stimulation, whereas specific mRNA for both cytokines was significantly decreased at day 3 (data not shown). $\beta$-actin and GAPDH served as housekeeping genes for normalisation. ${ }^{* \star *} P<0.001$.

relation to the concentrations of salivary leptin used or the duration of stimulation.

In the culture medium collected from the identical assay, a significant dose- and time-dependency was observed for both EGF and KGF expression after incubation with salivary leptin.

EGF values remained low in culture supernatants without stimulation with leptin (day 1: $7 \cdot 1 \pm 1 \cdot 8 \mathrm{pg} / \mathrm{ml}$; day $2: 5.7 \pm 1.8 \mathrm{pg} / \mathrm{ml}$; day $3: 7 \cdot 2 \pm 2.0 \mathrm{pg} / \mathrm{ml}$; n.s.). In contrast, incubation with $20 \mathrm{ng} / \mathrm{ml}$ leptin led to significantly increased EGF values after 48 and $72 \mathrm{~h}$ (day 1: $7 \cdot 2 \pm 0 \cdot 4 \mathrm{pg} / \mathrm{ml}$; day $2: 22 \cdot 1 \pm 1 \cdot 3 \mathrm{pg} / \mathrm{ml}$; day 3 : $28.9 \pm 4.6 \mathrm{pg} / \mathrm{ml} ; \quad P<0.001)$. The dose- and timedependency of leptin on EGF release is presented in Fig. 5a. When normalised to the daily control value without leptin incubation, it represents an increase of $206 \%$ at $48 \mathrm{~h}$ and $300 \%$ at $72 \mathrm{~h}(P<0 \cdot 001)$.

The other growth factor KGF was found in considerably higher concentrations in the keratinocyte supernatants. Without prior incubation with leptin, values of $83 \cdot 7 \pm 39 \cdot 7 \mathrm{pg} / \mathrm{ml}$ (day 1), $198 \pm 22 \cdot 1 \mathrm{pg} / \mathrm{ml}$ (day 2) and $221 \cdot 8 \pm 29 \cdot 3 \mathrm{pg} / \mathrm{ml}$ (day 3 ) were found. The stimulation with the maximal leptin concentration $(20 \mathrm{ng} / \mathrm{ml})$ also led to significantly increased values after 48 and $72 \mathrm{~h}$ (day 1: $87 \cdot 4 \pm 2.7 \mathrm{pg} / \mathrm{ml}$; day 2: $310 \cdot 2 \pm 9 \cdot 4 \mathrm{pg} / \mathrm{ml}$; day 3: $540 \cdot 9 \pm 63 \cdot 7 \mathrm{pg} / \mathrm{ml}$ ). The continuous rise of $\mathrm{KGF}$ concentrations in relation to the incubation with leptin is shown in Fig. 5b. After normalisation to the daily control value without leptin stimulation we calculated an increase of $355 \%$ after $48 \mathrm{~h}$ and $619 \%$ after $72 \mathrm{~h}(P<0 \cdot 001)$.

For both growth factors we found significant increases in release at lower, physiological doses of salivary leptin. The findings of this experiment indicate that salivary leptin is a potent stimulus for the expression of the two cytokines relevant to keratinocyte proliferation. Interestingly, KGF expression rises in non-stimulated cells during the 3 days, whereas EGF concentrations remained unchanged in the supernatants of cells without incubation with leptin.

\section{Cell proliferation assay}

Near physiological amounts of salivary leptin enhanced the proliferation of keratinocytes. A significant increase in DNA synthesis was demonstrated in concentrations as low as $2.5 \mathrm{ng} / \mathrm{ml}(P<0.05 ; 5 \mathrm{ng} / \mathrm{ml}: P<0.01 ; 10$ and $20 \mathrm{ng} / \mathrm{ml}: P<0 \cdot 001)$. Using the same concentrations of recombinant human leptin, an almost identical effect could be observed (Fig. 6a). Moreover, sterile dilutions of whole saliva with the native content of salivary leptin also led to a dose-dependent increase in BrdU incorporation (Fig. 6b) compared with the cells in saliva-free culture medium.

The findings so far indicated that salivary leptin, in addition to other salivary factors, promotes oral keratinocyte proliferation. Consequently, we wished to determine to what extent oral keratinocyte proliferation is based on an interrelationship between salivary leptin and the two other cytokines EGF and KGF, which were found to be upregulated by incubation with salivary leptin. The simultaneous incubation of the cells with a constant concentration of salivary leptin $(10 \mathrm{ng} / \mathrm{ml})$ and antibodies against either leptin or EGF or KGF was designed to capture one of the three cytokines and investigate their individual significance for the proliferation of the keratinocytes.

We found that the addition of antibodies raised against human leptin neutralises the positive effect of salivary leptin on keratinocyte proliferation (Fig. 7a). The proliferation remained on a significantly lower level compared with the leptin-stimulated control cells $(P<0 \cdot 001)$. Moreover, the addition of antibodies raised against human KGF led to comparable effects with the proliferation remaining at levels much lower in comparison with leptin-stimulated cells without simultaneous inhibition by antibodies $(P<0 \cdot 001)$. In contrast, the addition of antibodies raised against human EGF did not significantly reduce the mitogenic effect of salivary leptin.

It was essential to prepare a control assay using non-specific rabbit IgG in order to guarantee that the inhibition of cell proliferation was based on the specific capturing of the cytokines and not on a general apoptotic effect of rabbit antibodies on human cells. 
(a)

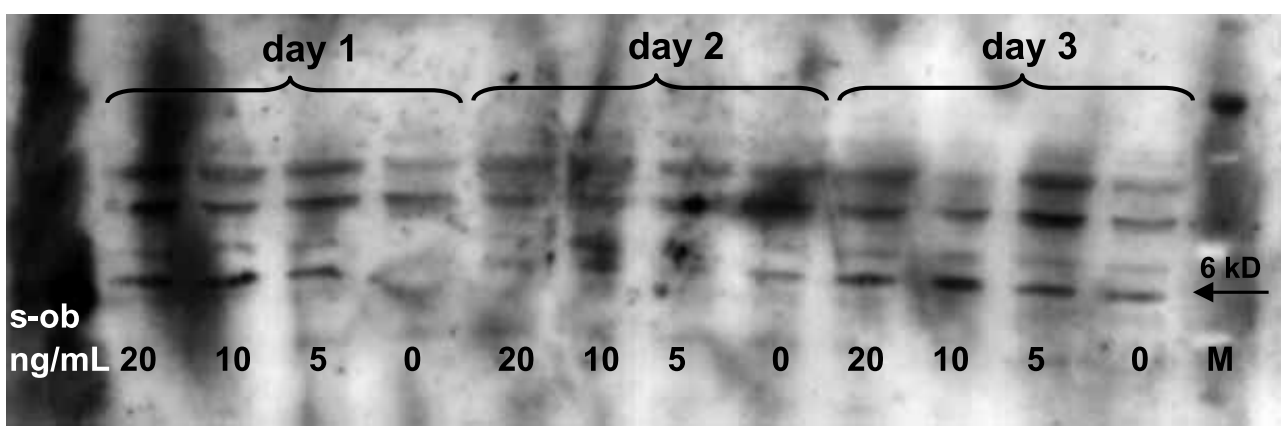

(b)

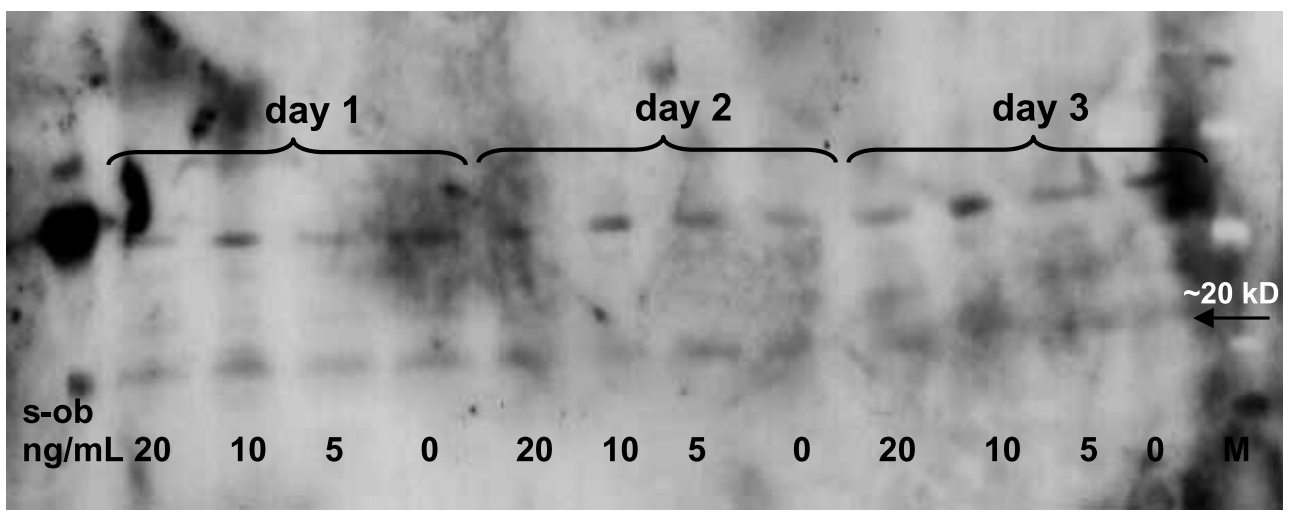

Figure 4 (a) Intracellular expression of EGF in salivary leptin-stimulated cells over 3 days and different leptin concentrations ( $\mathrm{ng} / \mathrm{ml}$, see text). In addition to the specific banding for EGF (6 kDa), additional non-specific bands were found. There was no significant difference between the protein levels between days and stimulation status. (b) Intracellular expression of KGF in salivary leptin-stimulated cells. Apart from the specific band ( $\sim 20 \mathrm{kDa}$, expected size $21 \mathrm{kDa})$, one additional band was localised at $\sim 80 \mathrm{kDa}$. There was no significant difference between the protein levels between days and stimulation status.

However, the addition of RIA grade rabbit IgG to the salivary leptin-stimulated cells did not hamper the proliferation. In fact, the stimulatory effect of salivary leptin on the cells was as significant as in the assay without addition of $\mathrm{IgG}$.

Finally our experiment using immunprecipitated human saliva showed that both salivary leptin and EGF equally contribute to the pro-proliferative effect of saliva $(P<0 \cdot 001)$, whereas saliva after removal of KGF was as stimulatory as under native conditions (Fig $7 \mathrm{~b}$ ). This was not surprising, since our analysis showed that native saliva does not contain KGF in detected concentrations (below the limit of quantification of our ELISA).

\section{Discussion}

The neuroendocrine activity of leptin in the metabolism of the adipose tissue as a trigger to the CNS has been intensively studied with special focus on the regulation of food intake (Seeley et al. 1996, Elmquist et al. 1998, Loftus 1999, Thomas et al. 2001). The discovery of leptin and Ob-R in the stomach (Bado et al. 1998, Breidert et al. 1999, Cinti et al. 2000) and the presence of leptin in saliva (Gröschl et al. 2001) have led to the suggestion that salivary leptin in the gastrointestinal tract and the oral cavity influences food uptake, digestion, or protection of the epithelia in an, as yet, unknown manner.

In the present study, we investigated the physiological function of leptin produced by the salivary glands on oral keratinocytes with a focus on a potential epithelial-protecting action.

Keratinocytes play an active part in local immune defence in oral mucosa and skin. They synthesise and release inflammatory cytokines and chemokines in response to a variety of environmental stimuli, such as bacterial products, ultraviolet light and other inflammatory cytokines (Kondo 1999). The impact of leptin as a mitogenic factor in skin repair has been intensively studied (Stallmeyer et al. 2001). 
(a)

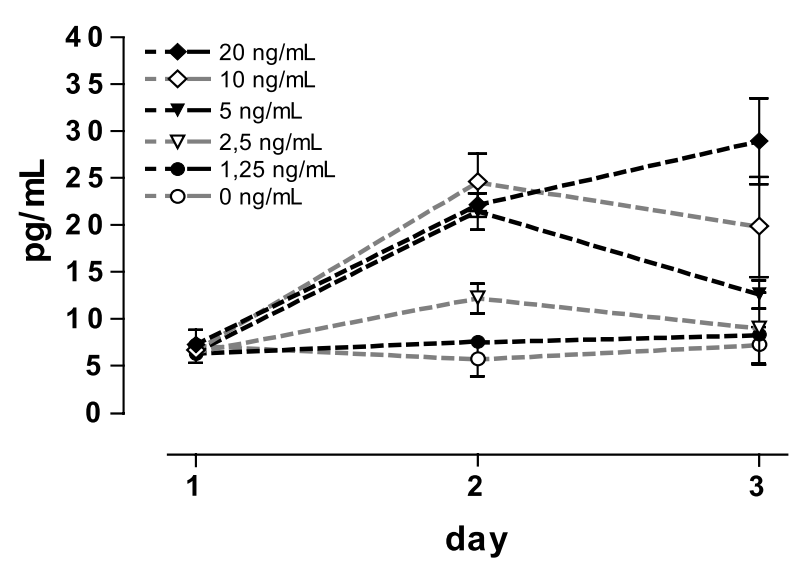

(b)

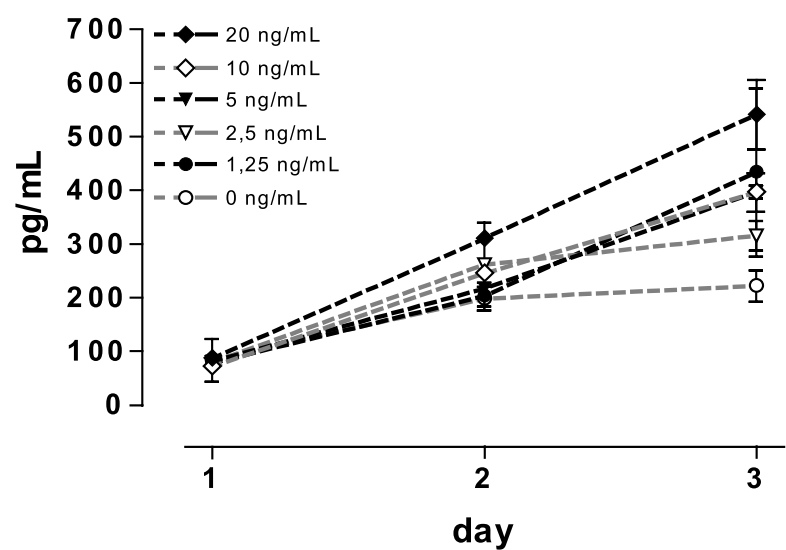

Figure 5 (a) Release of EGF in supernatants of salivary leptin-stimulated keratinocytes. A significant dose- and time-dependency was observed after incubation with both low and higher doses of salivary leptin $(P<0.001)$. In comparison with the daily control value $(0 \mathrm{ng} / \mathrm{ml})$, the highest leptin concentration $(20 \mathrm{ng} / \mathrm{ml})$ led to a $206 \%$ increase after $48 \mathrm{~h}$ and to a $300 \%$ increase after $72 \mathrm{~h}(P<0.001)$. (b) Release of KGF in supernatants of salivary leptin-stimulated keratinocytes. A significant dose- and time-dependency was observed after incubation with both low and higher doses of salivary leptin $(P<0.001)$. In comparison with the daily control value $(0 \mathrm{ng} / \mathrm{ml})$, the highest leptin concentration $(20 \mathrm{ng} / \mathrm{ml})$ led to a $355 \%$ increase after $48 \mathrm{~h}$ and to a $619 \%$ increase after $72 \mathrm{~h}$ $(P<0.001)$. Data are expressed as means \pm S.D. $(n=4)$.

It was therefore of special interest to investigate the impact of salivary leptin on EGF and KGF, the latter known to be expressed by oral keratinocytes (Formanek et al. 1999) and their contribution to proliferation of these particular cells.

It was important to confirm the presence of the specific cytokine receptors in the cells used for our experiments. In addition to previous findings demonstrating the presence of $\mathrm{Ob}-\mathrm{R}$ in the salivary glands (Bohlender et al. 2003), we confirmed by Western (a)

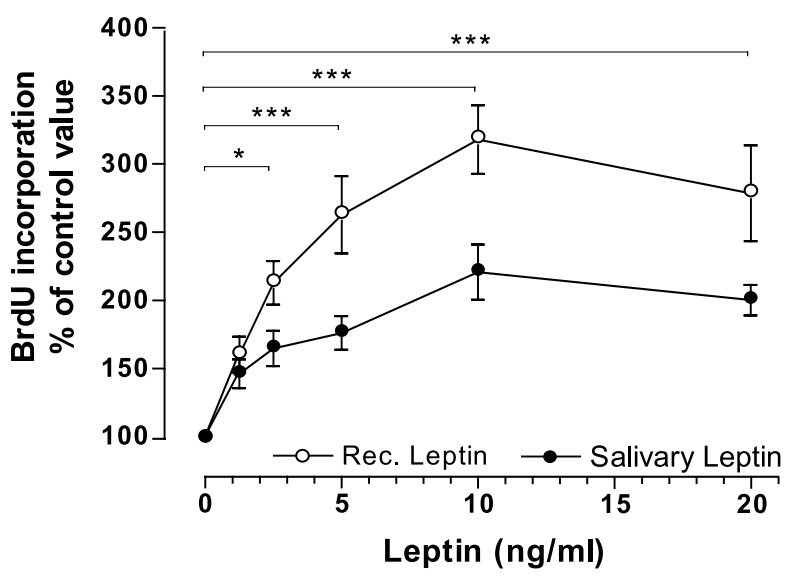

(b)

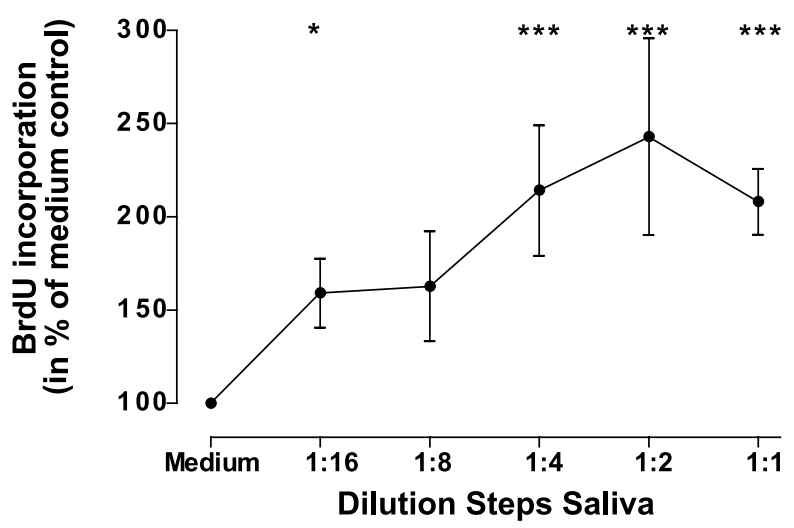

Figure 6 (a) Proliferation of human oral keratinocytes after incubation with leptin compared with medium controls $(2.5 \mathrm{ng} / \mathrm{ml}: P<0.05 ; 5 \mathrm{ng} / \mathrm{ml}: P<0.01 ; 10$ and $20 \mathrm{ng} / \mathrm{ml}$ : $P<0.001)$. $\bigcirc$ Cells incubated with recombinant human leptin. - Cells incubated with salivary leptin obtained from human saliva by affinity chromatography and lyophilisation. Index for proliferation of the cells is the incorporation of BrdU into the DNA. Data are expressed as means \pm S.D. $(n=10)$. (b) BrdU incorporation in cells incubated with sterile filtered human saliva, serially diluted in PBS and mixed with an equal volume of medium compared with the medium controls $\left({ }^{*} P<0.05\right.$; ${ }^{* * *} P<0.001$ ). Index for proliferation of the cells is the incorporation of BrdU into the DNA. Data are expressed as means \pm S.D. $(n=10)$.

blotting that oral keratinocytes are potential target cells for the three cytokines of interest, which has been described previously for KGF (Partridge et al. 1996, Drugan et al. 1997) and EGF (Jurukovski \& Simon 2000). Furthermore we could demonstrate the functionality of the $\mathrm{Ob}-\mathrm{R}_{\mathrm{b}}$ expressed by the keratinocytes. The incubation with salivary leptin led to the phosphorylation of STAT-1 and STAT-3. Concerning the Ob- $\mathrm{R}_{\mathrm{b}}$ isoform, STAT-3 and STAT-1 have been described as the most common second messengers 

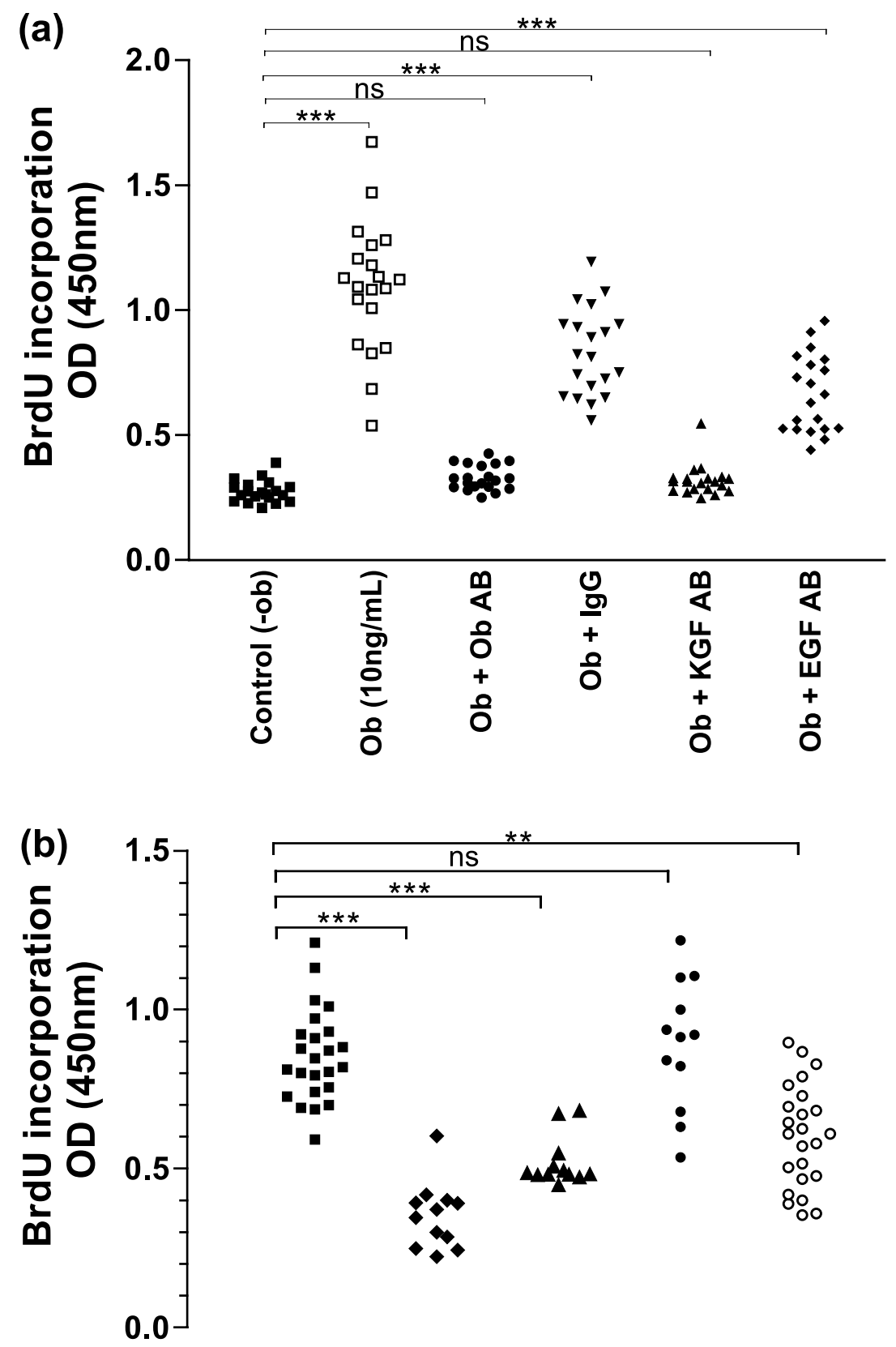

Figure 7 (a) BrdU incorporation in oral keratinocytes incubated simultaneously with $10 \mathrm{ng} / \mathrm{ml}$ salivary leptin and antibodies against either leptin, or EGF or KGF. Leptin antibodies neutralised the enhanced proliferation following salivary leptin incubation $\left({ }^{\star \star \star} P<0.001\right)$. Antibodies against KGF also reduced proliferation significantly $\left.{ }^{\star \star \star} P<0.001\right)$ whereas antibodies against EGF had no significant effect. The control assay using non-specific rabbit IgG did not hamper the proliferation. (b) BrdU incorporation in cells incubated with sterile filtered human saliva (1:1 in culture medium) with its native cytokine composition, and after immunprecipitation of leptin, EGF or KGF, compared with the controls with PBS replacing saliva $\left({ }^{\star \star} P<0 \cdot 01 ;{ }^{\star \star \star} P<0 \cdot 001\right)$. Index for proliferation of the cells is the incorporation of BrdU into the DNA. 

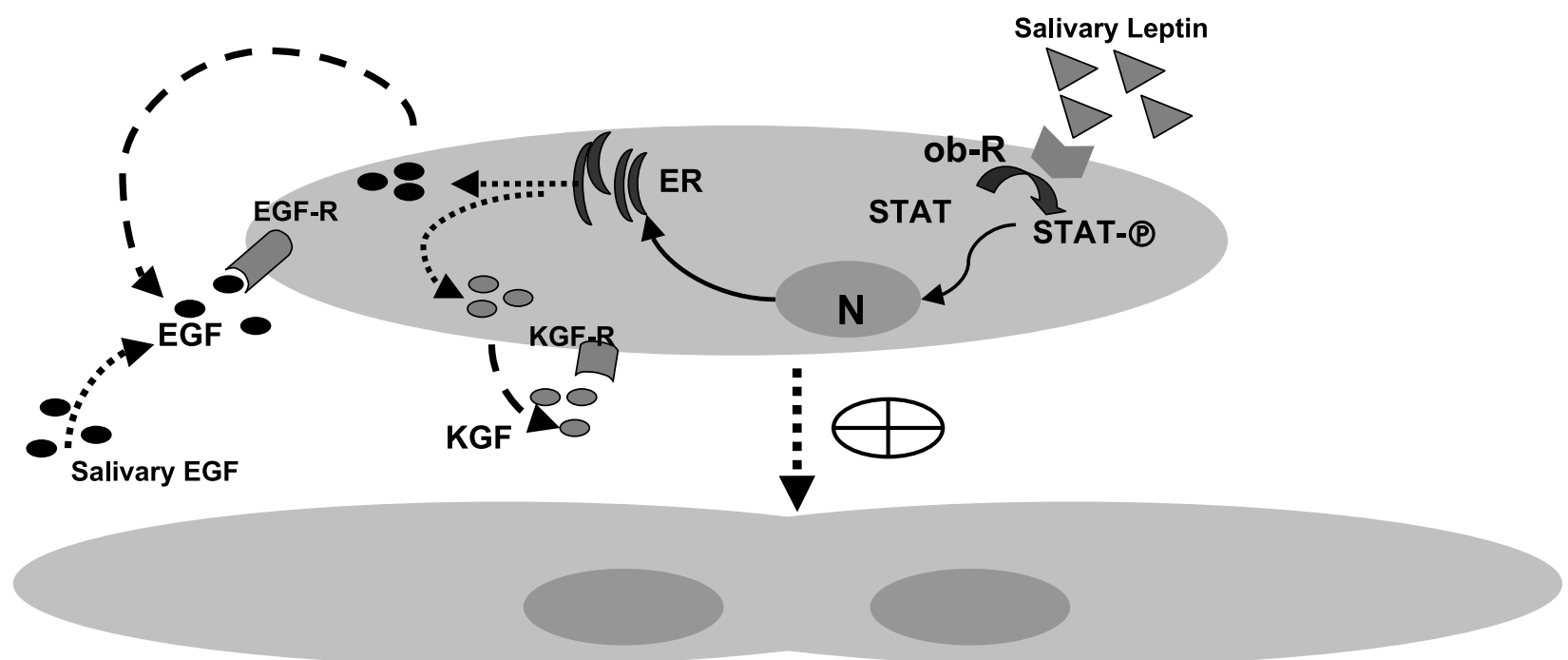

Figure 8 Hierarchical system of cytokine action in keratinocyte proliferation. Salivary gland-derived leptin binds to Ob-R molecules, using STAT phosphorylation as the second messenger. The following increased expression of EGF and KGF leads to the release of these cytokines by the cell. Both cytokines accelerate keratinocyte proliferation in addition to salivary leptin (and also salivary EGF). N: nucleus, ER: endoplasmatic reticulum; s-Ob: salivary leptin; Ob-R: leptin receptor; STAT: signal transducer and activator of transcription; EGF: epidermal growth factor; KGF: keratinocyte growth factor.

(Rosenblum et al. 1996, Hakansson \& Meister 1998, Bendinelli et al. 2000). We therefore agree with recent findings describing the leptin signalling pathways in human and murine keratinocytes (Stallmeyer et al. 2001, Goren et al. 2003). However, it remains to be fully determined whether the signal transduction via the JAK/STAT pathway is responsible for the increased keratinocyte proliferation.

This study shows that native leptin isolated from human saliva exhibits biological activity comparable to recombinant leptin on oral keratinocytes in culture. The pro-proliferative effect has been shown before for non-oral keratinocytes, but only using recombinant leptin (Frank et al. 2000, Goren et al. 2003). We were able to elucidate the importance of salivary leptin on oral cell proliferation by investigating the effect of salivary leptin on the expression and production of further pro-proliferative cytokines. Both EGF and KGF were significantly upregulated by salivary leptin on mRNA and protein level. It was extremely interesting to find that mRNA for both cytokines was dosedependently upregulated over 2 days followed by a sharp decline on day 3 , showing that the cellular answer to the leptin stimulation on the RNA level does not parallel the protein synthesis. However, we consider this finding understandable, since protein synthesis is known to be a longer-lasting process than RNA transcription.

We were surprised to find EGF release into the culture medium remaining unchanged over 3 days without prior stimulation with salivary leptin. The slight decrease in the EGF values in the supernatant on day 3 in some leptin concentrations ( 5 and $10 \mathrm{ng} / \mathrm{ml}$ ) may be explained by the degradation of the peptide, or adhesion to the plate surface.

In contrast, KGF release was gradually increased by the non-stimulated keratinocytes proliferating on a basal level. Knowing that EGF is present in human saliva (Olsen et al. 1984, Tebar et al. 2000, Thulesen et al. 2002) but not KGF, we interpret these data to indicate that EGF, supported by leptin, is predominantly an exogenous, saliva-derived stimulus for growing oral keratinocytes, whereas KGF is the main endogenous growth factor in keratinocyte proliferation (Slonina et al. 2001, Dörr et al. 2002, Sanaie et al. 2002). This hypothesis is underlined by our finding that the inhibition of KGF action by adding specific antibodies suppresses keratinocyte proliferation to a basal level. In contrast, the addition of antibodies against EGF did not reduce proliferation significantly. Moreover, this hypothesis is supported by recent publications demonstrating the importance of salivary EGF on cutaneous wound healing (Jahovic et al. 2004).

It was also interesting to observe that the inhibition of salivary leptin by simultaneous addition of antibodies against leptin reduced the proliferation to a basal level. We therefore postulate a hierarchical system of cytokine action in keratinocyte proliferation, which we have summarised in Fig. 8. In this model we represent figuratively the effect of salivary leptin binding to Ob-R molecules, leading to an increased expression of EGF and KGF possibly via STAT phosphorylation. The release of these cytokines and their autocrine 
or paracrine binding to specific receptors, finally accelerates the cellular proliferation.

So far we have demonstrated that salivary leptin shows significant physiological effects in oral keratinocytes. This is important for wound healing in the extremely vulnerable oral mucosa. The wound-healing effect of saliva is well known in animals (Bodner 1991, Bodner et al. 1992, 1993) and salivary cytokines such as salivary leptin, together with salivary EGF, may be responsible for this in addition to the cooling and antiseptic effects of saliva (Hart et al. 1987, Hart \& Powell 1990). As shown in our study, sterile filtered native saliva containing salivary leptin and many other salivary components such as EGF and also the recently discovered ghrelin (Gröschl et al. 2005) accelerates keratinocyte proliferation, clearly demonstrating the importance of saliva for oral health.

It fits in very well with the findings of our study, that leptin has recently emerged as an important regulator of mucosal inflammatory response to bacterial infection. It has been shown that recombinant leptin prevents the reduction in salivary mucin synthesis by oral bacterial lipopolysaccharides (Slomiany \& Slomiany 2003). Furthermore, a recent study of Ducroc et al. (2005) using Ussing chamber technology, proves that there are significant differences between leptin action in the circulation and in the gastrointestinal lumen. The authors demonstrated the inhibition of glucose uptake in rat jejunum being significantly decreased when leptin was supplied from the luminal in comparison with the serosal compartment.

Based on these findings and the data provided in our study, it becomes clear that salivary leptin may be a multifunctional factor in the maintenance of oral health.

\section{Acknowledgements}

The authors thank Mrs P Schmid for linguistic editing and $\operatorname{Dr} \mathrm{R}$ Schimming (Department of Oral and Maxillofacial Surgery, University of Freiburg, Germany) for providing the human keratinocytes. This study was funded by the Stiftung für Pathobiochemie und Molekulare Diagnostik der Deutschen Vereinten Gesellschaft für Klinische Chemie und Laboratoriumsmedizin e.V., and the ELAN-Fonds of the University of Erlangen. The authors declare that there is no conflict of interest that would prejudice the impartiality of this scientific work.

\section{References}

Alison MR \& Sarraf CE 1994 The role of growth factors in gastrointestinal cell proliferation. Cell Biology International 18 1-10.

Bado A, Levasseur S, Attoub S, Kermorgant S, Laigneau JP, Bortoluzzi MN, Moizo L, Lehy T, Guerre Millo M, Le-Marchand Brustel Y et al. 1998 The stomach is a source of leptin. Nature 394 790-793.
Banks AS, Davis SM, Bates SH \& Myers MGJ 2000 Activation of downstream signals by the long form of the leptin receptor. Fournal of Biological Chemistry 275 14563-14572.

Bendinelli P, Maroni P, Pecori-Giraldi F \& Piccoletti R 2000 Leptin activates Stat3, Statl and AP-1 in mouse adipose tissue. Molecular and Cellular Endocrinology 168 11-20.

Bodner L 1991 Effect of parotid submandibular and sublingual saliva on wound healing in rats. Comparative Biochemistry and Physiology 100 887-890.

Bodner L, Dayan D, Oberman M, Hirshberg A \& Tal H 1992 Healing of experimental wounds in sialadenectomized rat. Fournal of Clinical Periodontology 19 345-347.

Bodner L, Dayan D, Pinto Y \& Hammel I 1993 Characteristics of palatal wound healing in desalivated rats. Archives of Oral Biology 38 $17-21$.

Bohlender J, Rauh M, Zenk J \& Gröschl M 2003. Differential distribution and expression of leptin and the functional leptin-receptor in major salivary glands of humans. Fournal of Endocrinology 178 217-223.

Breidert M, Miehlke S, Glasow A, Orban Z, Stolte M, Ehninger G, Bayerdorffer E, Nettesheim O, Halm U, Haidan A et al. 1999 Leptin and its receptor in normal human gastric mucosa and in Helicobacter pylori-associated gastritis. Scandinavian Fournal of Gastroenterology 34 954-961.

Brzozowski T, Konturek PC, Konturek SJ, Pajdo R, Duda A, Pierzchalski P, Bielanski W \& Hahn EG 1999 Leptin in gastroprotection induced by cholecystokinin or by a meal. Role of vagal and sensory nerves and nitric oxide. European Fournal of Pharmacology 374 263-276.

Cinti S, De Matteis R, Pico C, Ceresi E, Obrador A, Maffei C, Oliver J \& Pulou A 2000 Secretory granules of endocrine and chief cells of human stomach mucosa contain leptin. International Fournal of Obesity 24 789-793.

De Matteis R, Puxeddu R, Riva A \& Cinti S 2002 Intralobular ducts of human major salivary glands contain leptin and its receptor. Fournal of Anatomy 201 363-370.

Dörr W, Spekl K \& Farrell CL 2002 The effect of keratinocyte growth factor on healing of manifest radiation ulcers in mouse tongue epithelium. Cell Proliferation 35 (Suppl 1) 86-92.

Drugan CS, Stone A, Game SM \& Prime SS 1997 The mitogenic effect of KGF and the expression of its cell surface receptor on cultured normal and malignant human oral keratinocytes and on contiguous fibroblasts. Fournal of Oral Pathology and Medicine 26 327-333.

Ducroc R, Guilmeau S, Akasbi K, Devaud H, Buyse M \& Bado A 2005 Luminal leptin induces inhibition of active intestinal absorption of glucose mediated by sodium-glucose co-transporter, SGLT-1. Diabetes 54 348-354.

Elmquist JK, Ahima RS, Maratos-Flier E, Flier JS \& Saper CB 1997 Leptin activates neurons in ventrobasal hypothalamus and brainstem. Endocrinology 138 839-842.

Elmquist JK, Maratos-Flier E, Saper CB \& Flier JS 1998 Unraveling the central nervous system pathways underlying responses to leptin. Nature Neuroscience 1 445-450.

Formanek M, Knerer B \& Kornfehl J 1999 Cytokine expression of human oral keratinocytes. Fournal of Oto-Rhino-Laryngology and its Related Specialties 61 103-107.

Frank S, Stallmeyer B, Kampfer H, Kolb N \& Pfeilschifter J 2000 Leptin enhances wound re-epithelialization and constitutes a direct function of leptin in skin repair. Fournal of Clinical Investigation $106501-509$.

Goren I, Pfeilschifter J \& Frank S 2003 Determination of leptin signaling pathways in human and murine keratinocytes. Biochemical and Biophysical Research Communications 303 1080-1085.

Gröschl M, Wagner R, Dörr HG, Blum WF, Rascher W \& Dötsch J 2000 Variability of leptin values measured from different sample matrices. Hormone Research 54 26-31. 
Gröschl M, Rauh M, Wagner R, Neuhuber W, Metzler M, Tamgüney G, Zenk J, Schoof E, Dörr HG, Blum WF et al. 2001 Identification of leptin in human saliva. Fournal of Clinical Endocrinology and Metabolism 86 5234-5239.

Gröschl M, Rauh M, Dörr HG, Blum WF, Rascher W \& Dötsch J 2002 Salivary leptin during the menstrual cycle and its relation to progesterone. Fertility and Sterility 77 1306-1307.

Gröschl M, Topf HG, Bohlender J, Zenk J, Klussmann S, Dötsch J, Rascher W \& Rauh M 2005 Identification of ghrelin in human saliva: expression by the salivary glands and potential role on the proliferation of oral keratinocytes. Clinical Chemistry (In Press).

Hackel P, Zwick E, Prenzel N \& Ullrich A 1999 Epidermal growth factor receptors: critical mediators of multiple receptor pathways. Current Opinion in Cell Biology 11 184-189.

Hakansson ML \& Meister B 1998 Transcription factor STAT3 in leptin target neurons of the rat hypothalamus. Neuroendocrinology 68 $420-427$.

Halaas JL \& Friedman JM 1997 Leptin and its receptor. Fournal of Endocrinology 155 215-216.

Hart BL \& Powell KL 1990 Antibacterial properties of saliva: role in maternal periparturient grooming and in licking wounds. Physiology and Behavior 48 383-386.

Hart BL, Korinek E \& Brennan P 1987 Postcopulatory genital grooming in male rats: prevention of sexually transmitted infections. Physiology and Behavior 41 321-325.

Higa M, Shimabukuro M, Fukuchi M, Komiya I \& Takasu N 2002 Atrophic change of rat salivary gland during adenovirus-induced hyperleptinemia. Biochemical and Biophysical Research Communications $291675-679$.

Hu X, Juneja SC, Maihle NJ \& Cleary MP 2002 Leptin - a growth factor in normal and malignant breast cells and for normal mammary gland development. Fournal of the National Cancer Institute $941704-1711$.

Iversen PO, Drevon CA \& Reseland JE 2002 Prevention of leptin binding to its receptor suppresses rat leukemic cell growth by inhibiting angiogenesis. Blood 100 4123-4128.

Jahovic N, Güzel E, Arbak S \& Yegen BC 2004 The healing-promoting effect of saliva on skin burn is mediated by epidermal growth factor (EGF): role of the neutrophils. Burns $\mathbf{3 0}$ 531-538.

Jurukovski V \& Simon M 2000 Epidermal growth factor signaling pathway influences retinoid metabolism by reduction of retinyl ester hydrolase activities in normal and malignant keratinocytes. Fournal of Cellular Physiology 183 265-272.

Kondo S 1999 The roles of keratinocyte-derived cytokines in the epidermis and their possible responses to UVA-irradiation. Fournal of Investigative Dermatology. Symposium Proceedings 4 177-183.

Konturek PC, Brzozowski T, Sulekova Z, Brzozowska I, Duda A, Meixner H, Hahn EG \& Konturek SJ 2001 Role of leptin in ulcer healing. European Fournal of Pharmacology 414 87-97.

Lammert A, Kiess W, Bottner A, Glasow A \& Kratzsch J 2001 Soluble leptin receptor represents the main leptin binding activity in human blood. Biochemical and Biophysical Research Communications 283 982-988.

Lauer G, Schimming R \& Frankenschmidt A 2001 Intraoral wound closure with tissue-engineered mucosa: new perspectives for urethra reconstruction with buccal mucosa grafts. Plastic and Reconstructive Surgery 107 25-33.

Loftus TM 1999 An adipocyte-central nervous system regulatory loop in the control of adipose homeostasis. Seminars in Cell and Developmental Biology 10 11-18.

Marchese C, Chedid M, Dirsch O, Csasky K, Santanelli F, Latini C, LaRocelle W, Torrisi M \& Aaronson S 1995 Modulation of keratinocyte growth factor and its receptor in reepithelializing human skin. Fournal of Experimental Medicine 182 1369-1376.

Martin Romero C, Santos Alvarez J, Goberna R \& Sanchez Margalet V 2000 Human leptin enhances activation and proliferation of human circulating T lymphocytes. Cellular Immunology 199 15-24.

Morash B, Li A, Murphy PR, Wilkinson M \& Ur E 1999 Leptin gene expression in the brain and pituitary gland. Endocrinology 140 5995-5998.

Morton NM, Emilsson V, Liu YL \& Cawthorne MA 1998 Leptin action in intestinal cells. Fournal of Biological Chemistry $\mathbf{2 7 3}$ 26194-26201.

Muoio DM \& Dohm GL 2002 Peripheral metabolic actions of leptin. Best Practice and Research. Clinical Endocrinology and Metabolism 16 653-666.

Olsen PS, Poulsen SS, Kirkegaard P \& Nexo E 1984 Role of submandibular saliva and epidermal growth factor in gastric cytoprotection. Gastroenterology 87 103-108.

Partridge M, Kiguwa S, Luqmani Y \& Langdon JD 1996 Expression of bFGF, KGF and FGF receptors on normal oral mucosa and SCG. European Fournal of Cancer. Part B Oral Oncology 32B 76-82.

Randeva H, Karteris E, Sailesh S, O'Hare P \& Hillhouse EW 2003 Circadian rhythmicity of salivary leptin in healthy subjects. Molecular Genetics and Metabolism 78 229-235.

Rosenblum CI, Tota M, Cully D, Smith T, Collum R, Qureshi S, Hess JF, Phillips MS, Hey PJ, Vongs A et al. 1996 Functional STAT 1 and 3 signaling by the leptin receptor (OB-R); reduced expression of the rat fatty leptin receptor in transfected cells. Endocrinology 137 5178-5181.

Sanaie AR, Firth JD, Uitto VJ \& Putnins EE 2002 Keratinocyte growth factor (KGF)-1 and -2 protein and gene expression in human gingival fibroblasts. Fournal of Periodontal Research 37 66-74.

Seeley RJ, van Dijk G, Campfield LA, Smith FJ, Burn P, Nelligan JA, Bell SM, Baskin DG, Woods SC \& Schwartz MW 1996 Intraventricular leptin reduces food intake and body weight of lean rats but not obese Zucker rats. Hormone and Metabolic Research 28 664-668.

Shintani S, Matsuo K, Crohin C, McBride J, Tsuji T, Donoff B, Posner M, Todd M \& Wong D 1999 Intergenic mutation analysis of human epidermal growth factor receptor (EGFR) gene in malignant human oral keratinocytes. Cancer Research $\mathbf{5 9}$ $4142-4147$.

Slomiany B \& Slomiany A 2003 Leptin suppresses Porphyromonas gingivalis lipopolysaccharide interference with salivary mucin synthesis. Biochemical and Biophysical Research Communications 312 1099-1103.

Slonina D, Hoinkis C \& Dörr W 2001 Effect of keratinocyte growth factor on radiation survival and colony size of human epidermal keratinocytes in vitro. Radiation Research 156 761-766.

Sobhani I, Buyse M, Goiot H, Weber N, Laigneau JP, Henin D, Soul JC \& Bado A 2002 Vagal stimulation rapidly increases leptin secretion in human stomach. Gastroenterology 122 259-263.

Stallmeyer B, Kämpfer H, Podda M, Kaufmann R, Pfeilschifter J \& Frank S 2001 A novel keratinocyte mitogen: regulation of leptin and its functional receptor in skin repair. Fournal of Investigative Dermatology 117 98-105.

Sweeney G 2002 Leptin signalling. Cellular Signalling 14 655-663.

Tebar F, Grau M, Mena MP, Arnau A, Soley M \& Ramirez I 2000 Epidermal growth factor secreted from submandibular salivary glands interferes with the lipolytic effect of adrenaline in mice. Endocrinology 141 876-882.

Thomas SA, Preston JE, Wilson MR, Farrell CL \& Segal MB 2001 Leptin transport at the blood-cerebrospinal fluid barrier using the perfused sheep choroid plexus model. Brain Research 895 283-290.

Thulesen J, Bor MV, Thulesen S, Nexo E, Poulsen SS \& Jorgensen PE 2002 Altered secretion and processing of epidermal growth factor in adrenergic-induced growth of the rat submandibular gland. Regulatory Peptides 106 105-114.

Tsuchiya T, Shimizu H, Horie T \& Mori M 1999 Expression of leptin receptor in lung: leptin as a growth factor. European fournal of Pharmacology 365 273-279. 
Visco V, Belleudi F, Marchese C, Leone L, Aimati L, Cardinali G, Kovacs D, Frati L \& Torrisi M 2004 Differential response to keratinocyte growth factor receptor and epidermal growth factor receptor ligands of proliferating and differentiating intestinal epithelial cells. Fournal of Cell Physiology 200 31-44.

Wang MY, Zhou YT, Newgard CB \& Unger RH 1996 A novel leptin receptor isoform in rat. FEBS Letters 392 87-90.

Wolf G, Hamann A, Han DC, Helmchen U, Thaiss F, Ziyadeh FN \& Stahl RA 1999 Leptin stimulates proliferation and TGF-beta expression in renal glomerular endothelial cells: potential role in glomerulosclerosis. Kidney International 56 860-872.

Wu MH, Chuang PG, Chen HM, Lin CG \& Tsai SJ 2002 Increased leptin expression in endometriosis cells is associated with endometrial stromal cell proliferation and leptin gene up-regulation. Molecular Human Reproduction 8 456-464.

Yoshizawa T, Watanabe S, Hirose M, Yamamoto J, Osada T, Sato K, Oide H, Kitamura T, Takei Y, Ogihara T et al. 2000 Effects of growth factors on aspirin-induced inhibition of wound repair in a rabbit gastric epithelial cell model. Alimentary Pharmacology and Therapeutics 14 (Suppl 1) 176-182.

Zhang HH, Kumar S, Barnett AH \& Eggo MC 2000 Ceiling culture of mature human adipocytes: use in studies of adipocyte functions. Fournal of Endocrinology 164 119-128.

Zhao J, Kunz TH, Tumba N, Schulz LC, Li C, Reeves M \& Widmaier EP 2003 Comparative analysis of expression and secretion of placental leptin in mammals. American Fournal of Physiology. Regulatory, Integrative and Comparative Physiology 285 R438-R446.

Zwick E, Hackel P, Prenzel N \& Ullrich A 1999 The EGF receptor as signal transducer of heterologous signalling systems. Trends in Pharmacological Sciences 20 408-412.

Received in final form 5 January 2005

Accepted 18 January 2005 